医療環境空気中に残留する抗がん剤及び臭気成分を光触媒によって分解する試み

\author{
佐藤淳也, ${ }^{*}, a, b$ 工藤賢三, ${ }^{a, b}$ 平野高広, ${ }^{c}$ 桑島孝幸, ${ }^{c}$ \\ 山田孫平, ${ }^{d}$ 雉鼻一郎, ${ }^{d}$ 佐藤一彦, ${ }^{e}$ 高橋勝雄 $a, b$
}

\title{
An Attempt to Degradation of Anticancer Drug and Odor in the Medical Environment by Photocatalyst
}

\author{
Junya Sato, ${ }^{*, a, b}$ Kenzo Kudo, ${ }^{a, b}$ Takahiro Hirano, ${ }^{c}$ Takayuki Kuwashima, ${ }^{c}$ \\ Sonpei Yamada, ${ }^{d}$ Ichiro Kijihana,${ }^{d}$ Kazuhiko Sato, ${ }^{e}$ and Katsuo Takahashi ${ }^{a}, b$ \\ ${ }^{a}$ Department of Pharmacy, Iwate Medical University Hospital; 19-1 Uchimaru, Morioka, Iwate 020-8505, \\ Japan: ${ }^{b}$ Department of Clinical Pharmaceutics, School of Pharmacy, Iwate Medical University; \\ 2-1-1 Nishitokuda, Yahaba-cho, Shiwa-gun, Iwate, 028-3694, Japan: 'Iwate Industrial \\ Research Institute; 3-35-2 Iiokashinden, Morioka, Iwate 020-0852, Japan: ${ }^{d}$ Nippon \\ Medical \& Chemical Instruments CO.,LTD.; 1-22-38 Edobori, Nishi-ku, \\ Osaka 550-0002, Japan: and ${ }^{~}$ Kamaishi Denkiseisakusho Co.Ltd.; \\ 3-3-15 Sadanai-cho, Kamaishi, Iwate 026-0053, Japan.
}

(Received April 24, 2012; Accepted June 17, 2012)

Currently, there is a need to reduce the occupational exposure of health care workers to anticancer drugs. Environmental contamination by anticancer drugs and subsequent exposure of health care workers are associated with vaporization of anticancer drugs. Furthermore, carcinomatous unpleasant odor is an additional problem to vaporized anticancer drugs in the field of clinical cancer therapy. We attempted to degrade vaporized anticancer drug and unpleasant odor using a photocatalyst. Cyclophosphamide or unpleasant odors (ammonia, formaldehyde, isovaleric acid, and butyric acid) were vaporized by heating in a closed chamber. Plates of photocatalyst coated with titanium dioxide were placed into the chamber and irradiated by light source. Vaporized cyclophosphamide in the chamber was recovered by bubbling the internal air through acetone and derivatized by trifluoroacetic anhydride for analysis by gas chromatographic-mass spectrometric assay. Vaporized odors were determined using a gas-detector tube, which changed color depending on the concentration. Following activation of the photocatalyst by a light source, the residual amounts of anticancer drug and unpleasant odor components were significantly decreased compared with when the photocatalyst was not activated without a light source. These results indicate that the photocatalysts can accelerate the degradation of vaporized anticancer drugs and odor components. Air-cleaning equipment using a photocatalyst is expected to be useful in improving the QOL of cancer patients experiencing carcinomatous unpleasant odor, and in reducing occupational exposure of health care workers to anticancer drugs.

Key words_ - occupational exposure; photocatalyst; titanium dioxide; cyclophosphamide; unpleasant odor

緒 言

現在，医療従事者の職業的抗がん剂被曝が国内外 で報告され，その低減が必要とされている. 1,2) 抗が 几剂の人体的被曝は, 皮膚からの吸収のほか, 気化 した抗がん剤が気道や口腔粘膜を経由して起こるこ

The authors declare no conflict of interest.

$a$ 岩手医科大学附属病院薬剂部, $b$ 岩手医科大学薬学部 臨床薬剂学講座, $c$ 岩手県工業技術センター, $d$ 株式会 社日本医化器械製作所, e株式会社釜石電機製作所

*e-mail: ZAP02377@ nifty.ne.jp
とも推定されている. 特に, シクロホスファミドな ど一部の抗がん剤は, 常温でも気化することが報告 されており，これら気化した抗がん剂が被曝に関与 していることが推測されている. 3 ,4) しかし，これら 気化する抗がん剂に対しては, 生物学的安全キャビ ネットや閉鎖式調製器具を使用して，作業環境中へ の放出を低減する技術はあるものの, 一度作業環境 中で気化・拡散した抗がん剂の低減方法は, 室内換 気以外にないのが現状である。そこで，筆者らは空 気清浄機での使用を想定し, 光触媒を用いて作業環 境中に気化した抗がん剤を分解できないか検討した。 


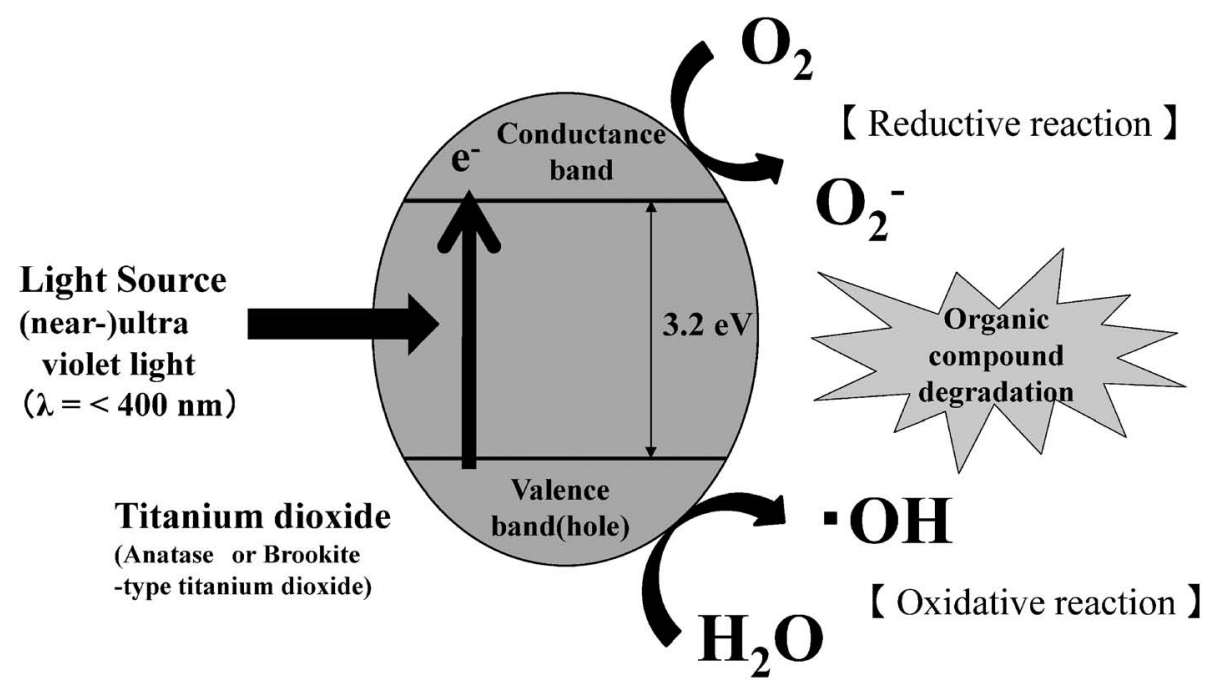

Fig. 1. Principle of Photocatalyst

When irradiated with light of wavelength less than $400 \mathrm{~nm}$ to titanium dioxide, electrons move from the valence band to the conductance band (hole), resulting in the band gap of $3.2 \mathrm{eV}$. Excited electron in the conduction band reacts with oxygen in the air, resulting in generation of superoxide anion $\left(\mathrm{O}_{2}^{-}\right)$. In the hole, $\mathrm{H}_{2} \mathrm{O}$ is oxidaised to hydroxyl radical $(\cdot \mathrm{OH})$. These reactive oxygen species degrade organic compounds.

光触媒とは，人体に無害な近紫外線（波長域 400 nm 以下）の光エネルギーから活性酸素を産生する 二酸化チタン等半導体である (Fig. 1). 光触媒か ら発生する活性酸素によって，あらゆる有機物を分 解する特性は, 抗菌性や空気清浄・脱臭能などとし て生活関連から医療産業にまで広く応用されてい る.5)これら光触媒の特性を考慮すると，がん医療 の環境においては光触媒によって医療従事者の被曝 を低減することのほか，医療関連臭（皮膚浸潤した 進行がん患者の組織腐臭やストーマ適用患者の便 臭，尿カテーテル適用患者の尿臭など）の低減が期 待される。しかし，光触媒による，環境中のこれら 臭気成分の分解性は報告されていない，光触媒を用 いた空気清浄機が，気化した抗がん剂を分解できれ ば，抗がん剤の環境的污染及び医療従事者の人体的 抗がん剂被曝を低減することが可能であると思われ る。また，同時に医療環境の臭気を低減すること は，患者及びその家族等への QOL 改善になること も期待される。そこで，本研究は，職業的抗がん剂 被曝のメルクマールとして代表的なシクロホスファ ミド及びがん医療現場の代表的臭気成分であるアン モニア（し尿臭）やホルムアルデヒド（繊維・リネ ン臭)，イソ吉草酸（腐敗臭），酪酸（体臭）に対す る光触媒の分解能について検討した.
方法

1. シクロホスファミドの気化及び回収方法 アセトンに溶解したシクロホスファミド（注射用 エンドキサン；塩野義製薬）溶液（20 mg/mL）を $35-40^{\circ} \mathrm{C}$ に維持した密閉チャンバー（容積； $43 \mathrm{~L}$ ） 内に静置したシャーレに $2 \mathrm{~mL}$ 滴下し，30 分間で 完全に気化させた．光触媒としては，チャンバー内 に設置した光触媒プレート（二酸化チタン粒子を表 面に均一に溶射させた $10 \mathrm{~cm}$ 四方のステンレス板 $\times 20$ 枚；秼釜石電気製作所）に，内蔵のブラック ライト（東芝 FL10BLBA, $10 \mathrm{~W} \times 2$ 本）から近紫外 線（波長 300-400 nm）を照射させた。チャンバー 内の空気は，エアポンプ（SIBATA MP- $53 ）$ によ って毎分 $1 \mathrm{~L}$ の速度で吸引し, 計 $5 \mathrm{~L}$ を $20 \mathrm{~mL}$ の アセトン中にバブリングさせることによって回収 し，バブリング後の空気は再びチャンバー内に還流 させた．気化したシクロホスファミドは， $0,1,3,5$ 時間毎に経時的に回収した（Fig. 2).

2. シクロホスファミドの測定サンプルの作製 各サンプリング時に回収したシクロホスファミド を含むアセトン溶液に，内標準物質（イホスファミ ドとして $500 \mathrm{ng}$ ）を加え，窒素ガス下で乾固させ た．これを酢酸エチル $150 \mu \mathrm{L}$ に溶解後，同量のト リフルオロ無水酢酸と混和して， $70^{\circ} \mathrm{C}$ にて 20 分間 反応させることによってフルオロアシル誘導体化し 


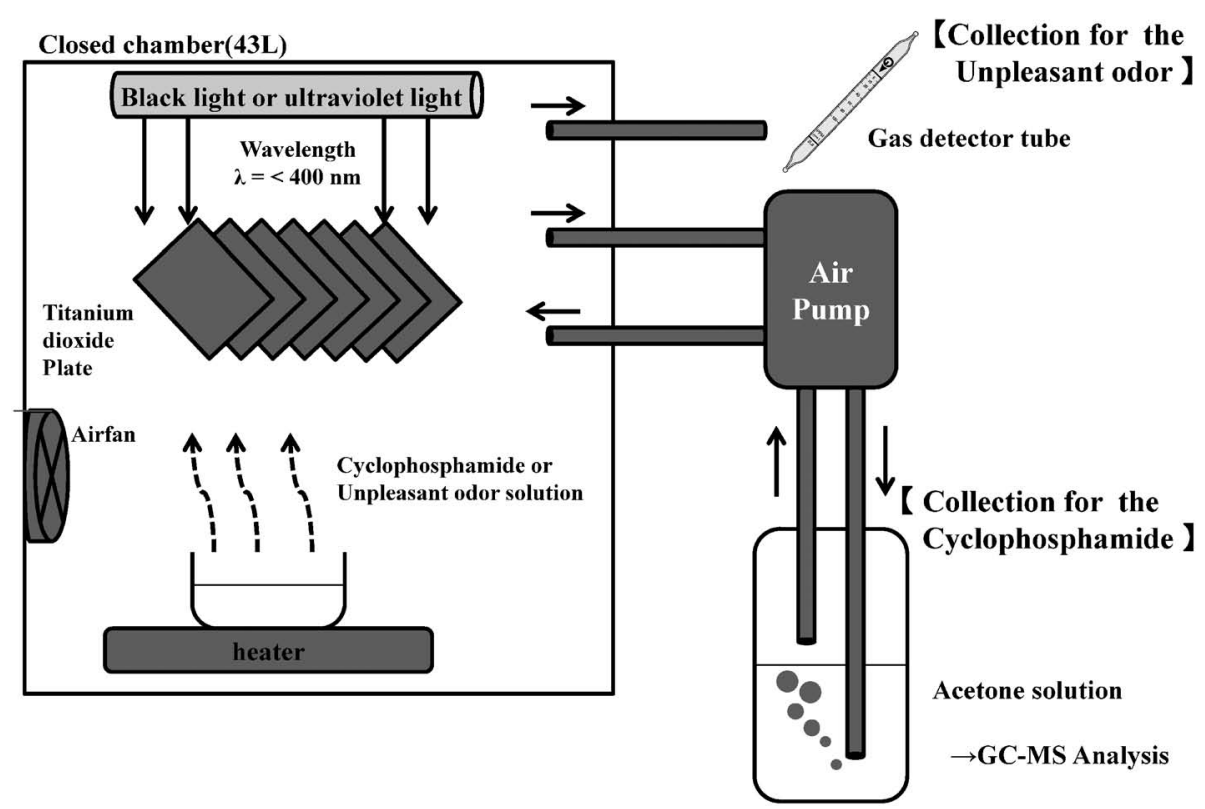

Fig. 2. Method for Measuring the Air Sample

Unpleasant odor or cyclophosphamide solution was vaporized by heating in the closed chamber. The photocatalyst was activated by ultraviolet light or black light. These components were degradated by photocatalyst. Photocatalytic degradation effect of each component was determined by measuring the internal gas to collect over time.

た。これを窒素ガス下で乾固後，100 $\mu \mathrm{L}$ のトルエ ンに溶解させたサンプルをガスクロマトグラフ質量 分析 (GC-MS) 法にて定量した.

3. GC-MS によるシクロホスファミド定量方法

GC-MS によるシクロホスファミド定量は，上記 操作によって調製したサンプル $5 \mu \mathrm{L}$ を Gerstel 社 製 TDU-CIS4 で濃縮・気化し splitless でカラムに 注入した. GC-MS は Agilent 社製 7890A 及び 5975C, カラムは Agilent 社製 DB-5 $(30 \mathrm{~m} \times 0.25 \mathrm{~mm} \times 0.25$ $\mu \mathrm{m})$ ，キャリアガスはヘリウム（流速 $24 \mathrm{~mL} / \mathrm{min}$ ) を使用し，オーブン温度は $70^{\circ} \mathrm{C}-\left(15^{\circ} \mathrm{C} /\right.$ 分 $)-250^{\circ} \mathrm{C}$ $(3$ 分 $)-\left(30^{\circ} \mathrm{C} /\right.$ 分 $)-300^{\circ} \mathrm{C}$ とした。誘導体化によって 生成した $N$-トリフルオロアセチルシクロフォスフ アミド及び内標準物質 $N$-トリフルオロアセチルイ ホスファミドを $307 \mathrm{~m} / \mathrm{z}$ のシングルイオンにて定 量した。定量限界は，サンプルエアー $5 \mathrm{~L}$ あたり $0.04 \mathrm{ng}$ であった。

4. 臭気成分の気化及び回収方法 シクロホス ファミドと同様のチャンバー内に $75 \mu \mathrm{L}$ のアンモニ ア水 $(28-30 \%(\mathrm{w} / \mathrm{v}))$ を内部に設置したシャーレ 内に滴下し， $40^{\circ} \mathrm{C}$ にて 30 分間で気化させた。気化 したアンモニア濃度は，気化直後及び $3,5,24$ 時間 目にチャンバー内空気 50-100 mL を気体採集器 （ガステック GV-100 S）にて吸引し，専用検知管
（ガステック；No. 3M（検出範囲 ；10-1000 ppm） と No. 3La（検出範囲；2.5-200 ppm)）にて呈色測 定した。光触媒の活性化は，紫外線殺菌灯（東芝 $\mathrm{GL}-10,10 \mathrm{~W} \times 2$ 本 ; 波長 $254 \mathrm{~nm})$ において行っ た.

アンモニアと同様に，ホルムアルデヒド，イソ吉 草酸及び酪酸においても同様に，それぞれ $100 \mu \mathrm{L}$ のホルムアルデヒド液 $(37 \%(\mathrm{w} / \mathrm{v})), 400 \mu \mathrm{L}$ のイ ソ吉草酸（98\% (w/v) ) 及び酪酸 $(98 \%(\mathrm{w} / \mathrm{v}))$ を, $40^{\circ} \mathrm{C}$ に維持したチャンバー内にて 3 時間で気化さ せた．これら臭気の濃度は，気化直後及び $1 ， 3 ， 5$, 24 時間目に，チャンバー内空気 50-100 mL を吸引 し，それぞれの検知管（ホルムアルデヒド（ガステ ック検知管 No. 91 ; 検出範囲；1-100 ppm）及びイ ソ吉草酸及び酪酸（ガステック検知管 No. 81 ; 検 出範囲；2-50 ppm)）にて呈色測定した.

5. 結果解析方法 シクロホスファミド及び臭 気成分の各測定值 $(n=2-3)$ は，気化直後の值を $100 \%$ として，チャンバー内残留濃度の変化率を経 時的に算出した。光触媒によるこれらの分解効果 は，光源を点灯させない条件を対照とした経時的残 存率を二元配置分散分析法 (Two-way ANOVA) 及び多重比較法（Fisher の最小有意差法）にて統計 的に比較した。光触媒による分解対象物の低減率 
は, 残存濃度差（光触媒なし-光触媒あり）/残存濃

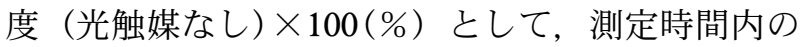
最大低減率を算出した。

結果

1. 光触媒によるシクロホスファミドの分解効果 チャンバー内にて気化したシクロホスファミド は，内部空気 $5 \mathrm{~L}$ あたり平均 $28 \mathrm{ng}(10-72 \mathrm{ng})$ が 検出された，光源により光触媒を作用させることに より，残留するシクロホスファミドは，光源を点灯 させず光触媒を作用させない場合に比べ有意に減少 し，3 時間目で 79\%の低減率を認めた（Fig. 3).

\section{2. 光触媒による臬気成分の分解効果}

2-1. アンモニアの分解効果 チャンバー内に て気化したアンモニアは，ガス検知管にて平均 308 ppm（250-350 ppm）が検出された。気化したアン モニアは，経時的に低減したが，光源により光触媒 を作用させることにより，光源を点灯せず光触媒を 作用させない場合に比べ有意に減少，24 時間目検 知管の検出限界以下の低下を認めた [Fig. 4(A)].

2-2. ホルムアルデヒドの分解効果 ホルムア ルデヒドにおいては，ガス検知管にて平均 $23 \mathrm{ppm}$ （20-25 ppm）が検出された。これに光触媒を作用 させることにより，光触媒を作用させない場合に比 ベホルムアルデヒド濃度は有意に減少し，24 時間 目で 77\%の低減率を認めた [Fig. 4(B)].
2-3. イソ吉草酸の分解効果 イソ吉草酸にお いては，ガス検知管にて平均 33 ppm（30-35 ppm）

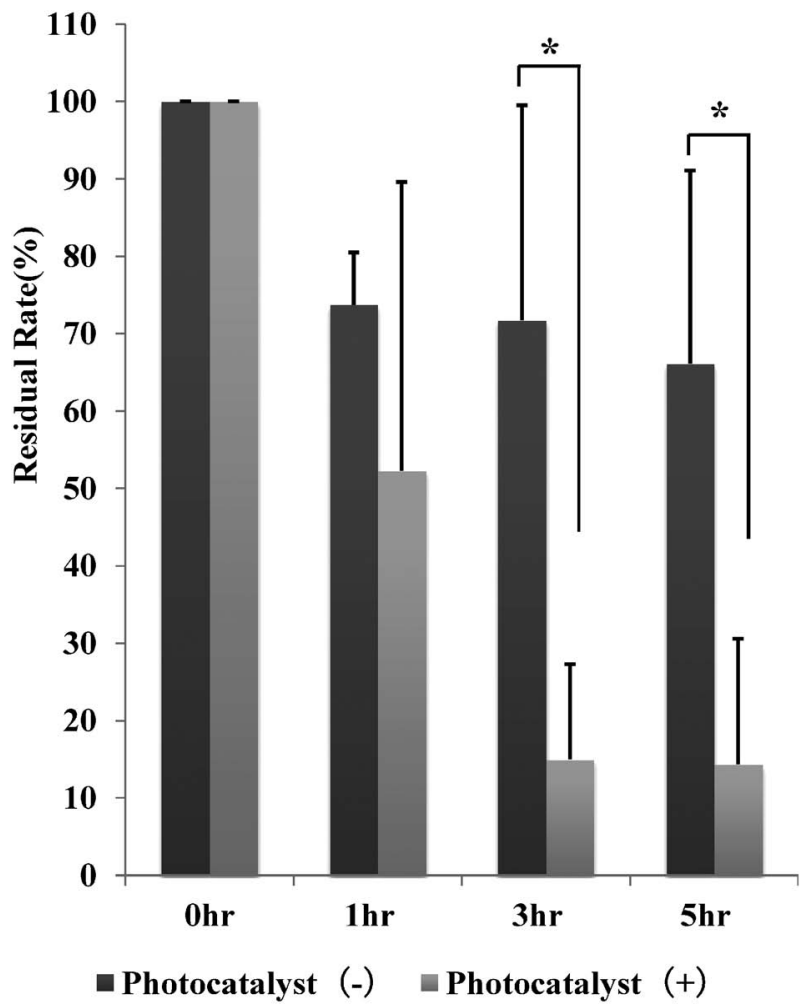

Fig. 3. Degradation Effect of Cyclophosphamide by Photocatalyst

The bar graph shows the residual rate of cyclophosphamide. Residual rates of internal cyclophosphamide gas using photocatalyst were significantly lower compared to the rates of the photocatalyst was not to be acting $(p<$ 0.001 by ANOVA and ${ }^{*} p<0.05$ by Fisher's least significant difference in each of reacting time).
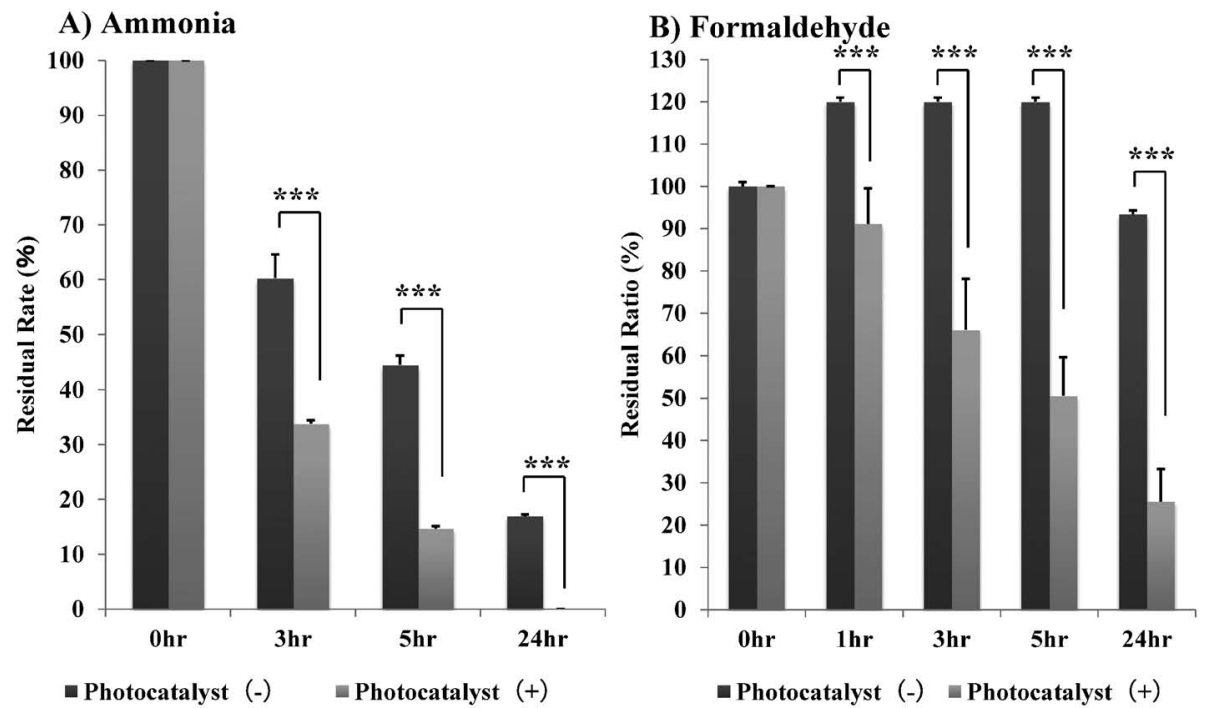

Fig. 4. Degradation Effect of Unpleasant Odor by Photocatalyst (A, Ammonia; B, Formaldehyde)

The bar graph shows the residual rate of unpleasant odor component. Residual rates of these components using photocatalyst were significantly lower compared to the rates of the photocatalyst was not to be acting ( $p<0.001$ by ANOVA and ${ }^{* * *} p<0.05$ by Fisher's least significant difference in each of reacting time) . 

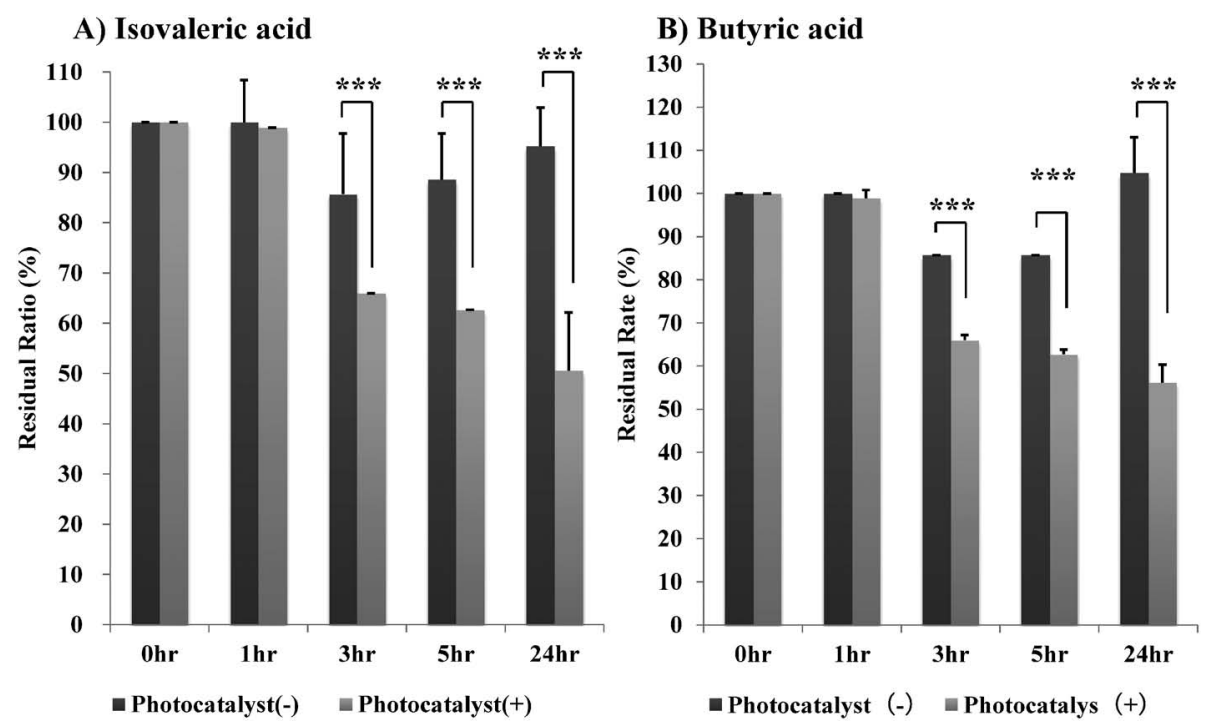

Fig. 5. Degradation Effect of Unpleasant Odor by Photocatalyst (A, Isovaleric Acid; B, Butyric Acid)

The bar graph shows the residual rate of unpleasant odor component. Residual rates of these components using photocatalyst were significantly lower compared to the rates of the photocatalyst was not to be acting ( $p<0.001$ by ANOVA and ${ }^{* * *} p<0.05$ by Fisher's least significant difference in each of reacting time) .

が検出された。これに光触媒を作用させることによ り，光触媒を作用させない場合に比ベイソ吉草酸濃 度は有意に減少し，24 時間目で $41 \%$ の低減率を認 めた [Fig. $5(\mathrm{~A})]$.

2-4. 酪酸の分解効果 酪酸においては, ガス 検知管にて平均 $33 \mathrm{ppm}(30-35 \mathrm{ppm})$ が検出され た.これに光触媒を作用させることにより, 光触媒 を作用させない場合に比べイソ吉草酸濃度は有意に 減少し，24 時間目で 54\%の低減率を認めた [Fig. $5(\mathrm{~B})]$.

考察

これまで，筆者らは生物学的安全キャビネット内 に残留する抗がん剂を光触媒である二酸化チタン懸 濁液として噴霧し, 近紫外線光 (あるいは紫外線光) を照射することによって，シクロホスファミドを含 む複数の抗がん剂を分解することを報告してき た. ${ }^{6,7)}$ 光触媒とは, 二酸化于タンを代表的に光の工 ネルギーを受けると酸化物表面から電子が放出され ると同時に，プラス電荷を持った正孔が生じる半導 体である、環境中の酸素は，マイナス電子と反応し スーパーオキサイドアニオン $\left(\cdot \mathrm{O}_{2}^{-}\right)$を生じ，正 孔では水から電子を奪い取り，ヒドロキシラジカル $(\cdot \mathrm{OH})$ が発生する. 特に, 強い酸化力を持つヒド ロキシラジカルは, 有機分子中の C-C 結合, C-H 結合, C-N 結合, C-O 結合, O-H 結合, N-O 結合
の結合解離エネルギーより大きな酸化エネルギーを 持つ。したがつて，あらゆる有機化合物の原子間結 合を容易に切断し，分子を分解する．防衛研究の分 野では，シクロホスファミドと類似構造を持つマス タード系毒ガスが，光触媒によって分解されること が報告されている. ${ }^{8)}$ また, 環境衛生の分野では,

下水中のステロイドホルモンを光触媒が完全に分解 する試みも報告されている. ${ }^{9)}$ さらに，大腸菌群の 死滅が報告されている. ${ }^{10)}$ そこで今回，これら光触 媒により有機物が分解される特性を空気清浄機とし て応用し，環境空気中に残留する抗がん剂を分解す る適用方法を試みた。

医療現場の環境的な抗がん剂污染については，常 温で気化するシクロホスファミドをメルクマールと してモニタリングされており, 調製室や投与環境等 あらゆる場所で検出されていることが報告されてい る. ${ }^{1,2)}$ 抗がん剂污染の原因としては, 現状主流の完 全排気型クラス IIb2 型生物学的安全キャビネット を使用していても調製者の腕などで前面エアバリア の気流が乱れ，内部の空気が調製者側に流出する可 能性があるほか, 閉鎖式調製器具を用いても, 病棟 詰所や病室での輸液ラインの付け替え時, 病室での 患者への投与終了後の不適切な輸液ラインの廃棄, さらには投与患者の排泄物（尿や便，汗，吐物）な どから微量のシクロホスファミドが飛散している可 能性がある。実際にクラス IIb2 型安全キャビネッ 
トや閉鎖式調製器具を使用している自施設の環境的 抗がん剂被曝モニタリング調査でも，調製環境外で あるナースステーションや病室でシクロホスファミ ドが検出されている. ${ }^{11)}$ これら環境的な抗がん剂污 染が，医療従事者の職業的な抗がん剂被曝につなが つているものと思われる，既存の被曝対策技術は， 特に調製環境から環境外に抗がん剂を流出させない 技術であり，調製室内やナースステーション，病室 などで一度飛散した抗がん剤を低減させる技術はほ とんどないと言える。今回の検討は，実験的なチャ ンバー内環境ながら，シクロホスファミドが気化す ることを示し，光触媒によってこれを分解できるこ とを示したものである. 調製環境外に污染した抗が ん剂を光触媒の分解能を利用した空気清浄機として 利用することは，医療従事者の職業的抗がん剂被曝 の低減に有用であると考えられる，今後，検体数を 増やし，これら紫外線灯での分解能や実際の臨床的 環境での測定，シクロホスファミド以外の気化する 薬剤についても検討が必要であると考えている.

光触媒を空気清浄機として使用する場合，空気中 抗がん剂を分解することに加え，医療上発生する臭 気を分解できることも有用性が高いものと思われ る. がん治療の現場では，がん治療に平行して病状 から床上排泄や清潔行為の制限を余儀なくされるが ん患者が少なくない。また，皮膚浸潤を抱えた患者 の臭気は，環境のみならず患者自身の QOL を低下 させる点で問題となっている。したがって，抗がん 剤と不快な臭気の発生源は，がん治療の環境におい て共在し，あらゆる有機物を分解する光触媒の特性 は，抗がん剂のみならず臭気気成分の分解にも有効 であると期待される。これら医療現場で問題となる 臭気成分と発生原因は，口臭・体臭成分であるイソ 吉草酸, 酪酸, ジメチルスルフィドやし尿臭成分で あるアンモニア，寝具等のアルデヒド類であること が推測されている. ${ }^{12)}$ 今回の検討でも，それぞれの 代表的成分であるアンモニア，ホルムアルデヒド， イソ吉草酸, 酪酸の分解を光触媒が加速させること を示した.

これまでの二酸化チタン懸濁液を用いて抗がん剂 分解能を評価した筆者らの検討では, 光触媒がシク ロホスファミドに対して，高い分解能を示すと同時 に, 分子構造や分子量 $(130-854)$, 作用機構 （DNA アルキル化，代謝拮抗，微小管阻害，トポ
イソメラーゼ阻害）が異なる複数の抗がん剂（メソ トレキサート，5-フルオロウラシル，パクリタキセ ル，イリノテカン）に対しても，高い分解能を認め ている，今回，抗がん剂や臭気についても，成分に よる被分解能の差はあるものの，気化した有機物を 光触媒が分解できることを示した．また，定量限界 の問題から，これら実験環境での負荷量（チャン バー内濃度）は，臨床現場での実際に比べ著しく高 いものに設定せざる得なかった。医療環境における 空気中シクロホスファミド濃度には，調製中の作業 者近傍において 0.03 未満 $-0.2 \mu \mathrm{g} / \mathrm{m}^{3}$ あるいは調製 室において $5 \mathrm{ng} / \mathrm{m}^{3}$ の定量限界以下など，測定条件 によって大きな違いがあると報告されている. ${ }^{13,14)}$ しかしながら，いずれも今回実験的に設定したチャ ンバー内の初期シクロホスファミド濃度（平均 5.6 $\left.\mu \mathrm{g} / \mathrm{m}^{3}\right)$ に比べ，大幅に低い污染量である。過去の 検討でも，分解対象物である抗がん剂の初期負荷量 が減少するに従い，分解率が大きく向上する傾向を 認めたことからも, 臨床環境では, 分解対象物であ る抗がん剤や臭気成分が少ない点で，より高い分解 率が期待されるものと思われる。しかし，今回の検 討では，抗がん剤分解生成物の構造決定までは至つ ていない，つまり，抗がん剂分解生成物にも変異原 性が残存していれば，光触媒によって化学構造上の 分解効果を認めても，人的被曝の影響を低減すると いう真の目的には至らない。抗がん剂を次亜塩素酸 や過マンガン酸カリウムなどの化学的分解剤で分解 を試みた報告では，分解剤と抗がん剂種によっては HPLC 分析上の抗がん剂残存率が低下していて も，変異原性は減らないあるいはむしろ増えている 現象も報告されている. ${ }^{15)}$ 一方，光触媒を用いた分 解剂では，環境的内分泌攪乱物質であるエストラジ オールが最終的に $\mathrm{CO}_{2}$ にまで分解し，バイオアッ セイにても効果を示さないことも報告されてい る. ${ }^{16)}$ 今後, 光触媒による抗がん剂分解の残留物の 毒性（変異原性）について評価する必要がある，ま た，臭気成分に対する分解能についても，実際の医 療現場において，人間による官能的な評価も必要で あると考えている.

以上より, 光触媒が環境空気中に残留する抗がん 剂を分解し，医療従事者の人体的被曝を低減できる ものと思われた。 また，がん医療環境で問題となる 臭気の分解にも有用であることからも，光触媒はが 
ん治療環境の改善に今後広く活用されることが期待 される.

\section{REFERENCES}

1) Sessink P. J., Kroese E. D., van Kranen H. J., Bos R. P., Int. Arch. Occup. Environ. Health, 67, 317-323 (1995).

2) Sugiura S., Itoh A., Tanimura M., Nakanishi H., Hama T., Miyagawa M., Mori K., J. Jpn. Soc. Hosp. Pharm., 44, 18-20 (2008).

3) Connor T. H., Shults M., Fraser M. P., Mutat. Res., 470, 85-92 (2000).

4) Yabunaka H., Sakaguchi F., Kobayashi Y., Nakanishi H., Jpn. J. Pharm. Health Care Sci., 36, 343-346 (2010).

5) Nakata K., Fujishima A., Farumashia, 45, 233 -237 (2009).

6) Sato J., Kudo K., Takimoto I., Sanbayashi M., Kijihana I., Takahashi K., Jpn. J. Pharm. Health Care Sci., 37, 57-61 (2011).

7) Sato J., Kudo K., Takimoto I., Sanbayashi M., Umezawa T., Kijihana I., Takahashi K., Jpn. J. Pharm. Health Care Sci., 37, 585-589 (2011).

8) Hirakawa T., Mera N., Sano T., Negishi N., Takeuchi H., Yakugaku Zasshi, 129, 71-92 (2009).
9) Ohko Y., Iuchi K., Niwa C., Tatsuma T., Nakashima T., Iguchi T., Kubota Y., Fujishima A., Environ. Sci. Technol., 36, 4175-4181 (2002).

10) Kikuchia Y., Sunada K., Iyoda T., Hashimoto K., Fujishima A., J. Photochem. Photobiol. A, Chem., 106, 51-56 (1997).

11) Sato J., Mori M., Kumagai M., Nakayama S., Yamauchi T., Kudo K., Takahashi K., J. Jpn. Soc. Hosp. Pharm., 48, 441-444 (2012).

12) Sakakibara A., Nishi A., Yuki F., Suzuki K., Ishida H., J. Jpn. Soc. Healthcare Admin., 45, 225 (2008).

13) Sessink P. J., Van de Kerkhof M. C., Anzion R. B., Noordhoek J., Bos R. P., Arch. Environ. Health, 49, 165-169 (1994).

14) Sessink P. J., Boer K. A., Scheefhals A. P., Anzion R. B., Bos R. P., Int. Arch. Occup. Environ. Health, 64, 105-112 (1992).

15) Benvenuto J. A., Connor T. H., Monteith D. K., Laidlaw J. L., Adams S. C., Matney T. S., Theiss J. C., J. Pharm. Sci., 82, 988-991 (1993).

16) Ohko Y., Iuchi K., Niwa C., Tatsuma T., Nakashima T., Iguchi T., Kubota Y., Fujishima A., Environ. Sci. Technol., 36, 4175-4181 (2002). 